\title{
Lymphatic Filariasis: A Systematic Review on Morbidity and Its Repercussions in Countries in the Americas
}

\author{
Zulma M. Medeiros ${ }^{1,2}$, Amanda V. B. Vieira ${ }^{1, *}$, Amanda T. Xavier ${ }^{1,2}{ }^{-}$, Gilberto S. N. Bezerra ${ }^{3}$, \\ Maria de Fátima C. Lopes ${ }^{4}$, Cristine V. Bonfim ${ }^{5,6}{ }^{-1}$ and Ana M. Aguiar-Santos ${ }^{1}$
}

Citation: Medeiros, Z.M.; Vieira, A.V.B.; Xavier, A.T.; Bezerra, G.S.N.; Lopes, M.d.F.C.; Bonfim, C.V.; Aguiar-Santos, A.M. Lymphatic Filariasis: A Systematic Review on Morbidity and Its Repercussions in Countries in the Americas. Int. J. Environ. Res. Public Health 2022, 19, 316. https://doi.org/10.3390/ ijerph19010316

Academic Editors: Fabrizio Bruschi and Stefano D'Amelio

Received: 31 October 2021

Accepted: 23 December 2021

Published: 28 December 2021

Publisher's Note: MDPI stays neutral with regard to jurisdictional claims in published maps and institutional affiliations.

Copyright: (C) 2021 by the authors. Licensee MDPI, Basel, Switzerland. This article is an open access article distributed under the terms and conditions of the Creative Commons Attribution (CC BY) license (https:// creativecommons.org/licenses/by/ $4.0 /)$.
1 Fundação Oswaldo Cruz, Departamento de Parasitologia, Instituto Aggeu Magalhães, Recife 50670-420, Brazil; zulma.medeiros@fiocruz.br (Z.M.M.); amanda-xavier@hotmail.com (A.T.X.); anamaria.aguiar@fiocruz.br (A.M.A.-S.)

2 Programa de Pós-Graduação em Ciências da Saúde, Universidade de Pernambuco, Recife 50100-130, Brazil

3 Materials Research Institute, Technological University of the Shannon: Midlands Midwest, N37 HD68 Athlone, Ireland; a00278630@student.ait.ie

4 Ministério da Saúde, Secretaria de Vigilância em Saúde, Brasília 70723-040, Brazil; fatimacostalopes@gmail.com

5 Ministério da Educação, Fundação Joaquim Nabuco, Diretoria de Pesquisas Sociais, Recife 52061-540, Brazil; cristine.bonfim@uol.com.br

6 Programa de Pós-Graduação em Saúde Coletiva, Universidade Federal de Pernambuco, Recife 50670-901, Brazil

* Correspondence: amandaa-vieira@outlook.com; Tel.: +55-81-21012662

\begin{abstract}
The Global Program to Eliminate Lymphatic Filariasis (GPELF) is a program that aims to eliminate lymphatic filariasis by 2030. The GPELF strategy is based on interrupting transmission using mass drug administration (MDA) and, in parallel, managing morbidity cases. However, it has been seen that there is a shortage of research in the literature and public policies regarding this last pillar. In this study, we reviewed the literature and available information regarding the burden of filarial morbidity. In addition, we identified that in the Americas, the implementation of structured services with regard to morbidity assistance in the Americas was scarce. We formed a review that aimed to assess the pathogenesis, epidemiology, repercussions, and treatment of filarial morbidity in countries in the Americas where lymphatic filariasis is endemic. Structured searches were carried out on PubMed, LILACS, Scopus, and Web of Science databases without time and language restrictions. Three reviewers evaluated the 2150 studies and performed data extraction, and quality assessment by assigning scores to the studies found. The current literature and available information on the burden of filarial morbidity, as well as the implementation of structured services with regard to morbidity assistance in the Americas, were all found to be scarce. Now that this knowledge gap has been identified, both health services and researchers need to seek the implementation and enhancement of the maintenance of GPELF strategies that relate to the morbidity pillar.
\end{abstract}

Keywords: lymphatic filariasis; morbidity; hydrocele; lymph scrotum; lymphoedema; acute dermatolymphangioadenitis; elephantiasis

\section{Introduction}

Lymphatic filariasis (LF) is a neglected tropical disease caused by Brugia malayi, Brugia timori, and Wuchereria bancrofti and over $90 \%$ of cases are caused by the last. These parasites are transmitted via a number of different mosquito hosts, which vary geographically. LF is considered endemic in 72 countries, and Brazil, the Dominican Republic, Guyana, and Haiti are the four remaining countries in the Americas where it is considered endemic [1]. The World Health Organization (WHO) classified this parasitic infection as the second most common cause of long-term disability after mental illness [2].

In 2000, the WHO launched the Global Program to Eliminate Lymphatic Filariasis (GPELF) with the aim of eliminating LF by 2030. The strategy of the GPELF is based 
on interrupting transmission using mass drug administration (MDA), and, in parallel, alleviating and preventing suffering and disability in those who already have chronic manifestations of the disease [3,4].

Morbidity in LF is expressed as painful and profoundly disfiguring visible chronic manifestations that include lymphoedema (acute dermatolymphangioadenitis-ADLA and elephantiasis) and male urogenital disease (hydrocele and lymph scrotum). ADLA bacterial infections cause significant pain and fever, and also occur in phases. Other less commonly reported clinical expressions include lymphoedema of the breast, swelling of the vulva, and rheumatic and respiratory problems [3].

The MDA program is advanced, and many endemic countries have introduced the strategy and achieved tremendous success, thus contributing to reducing global LF infection rates from 120 million individuals in 1997 to 56 million individuals in 2017 [4]. However, morbidity management remains less widespread and unsuccessful, and the literature is scarcer, and less information is available regarding the implementation of programs that aim to address this pillar [5].

The objectives of this review were to analyze the main findings regarding the pathogenesis, epidemiology, repercussions, and treatment of filarial morbidity that have been adopted in countries in the Americas where lymphatic filariasis is endemic, in order to support the progress of the GPELF with regard to the pillar of morbidity.

\section{Materials and Methods}

In this systematic review, we adhered to the PRISMA 2020 guidelines and checklistPreferred Reporting Items for System Reviews and Meta-Analyses [6] to reduce the possibility of inserting bias.

\subsection{Data Sources and Search Strategy}

A bibliographic survey was carried out by looking for scientific articles from May 1987 to July 2021, without restrictions with regard to the year of publication and language. Searches were performed in national and international databases (LILACS (Latin American and Caribbean Literature on Health Sciences), PubMed (National Center Biotechnology Information), Scopus (Elsevier), and Web of Science (Clarivate Analysis)).

For this, the following search-key was used: (((Elephantiasis, Filarial) OR ("lymphatic filariasis" OR filaria *)) AND ( $\left.\mathrm{m}^{*}\right)$ OR (elephantias * OR hydrocel * OR (lymphoedema OR lymphoedema) OR lymphadenopathy * OR ("Acute dermatolymphangioadenit *" OR ADLA) OR lymphangit *))) AND (Brazil OR Guyana OR "Dominican Republic" OR Haiti OR “Trinidad and Tobago" OR “Costa Rica” OR Suriname).

\subsection{Study Selection and Data Extraction}

Initially, the articles were selected independently by 2 reviewers (ATX and AVBV). Before the screening, duplicate studies were removed, and the remaining studies passed through to the first selection stage (reading of titles and abstracts). After this first screening, some studies were considered ineligible, and the remainder were sent to the next stage of the selection process (reading the full text). In this phase, in addition to data extraction, eligibility standards were validated once again. In the presence of any disagreement, a more experienced third reviewer (AMAS) made their assessment. The inclusion criteria for this review were as follows: (i) LF morbidity cases (male urogenital disease and lymphoedema); (ii) endemic countries and those that have already received LF elimination verification in the Americas. Articles were excluded if (i) they did not agree with the inclusion criteria and addressed cases of filarial morbidity in locations other than the Americas; (ii) they were narrative, systematic literature reviews with or without meta-analyses; (iii) book chapters; (iv) conference publications; (v) letters to editors; (vi) case reports, and (vii) studies that do not address morbidities.

From the analysis of the inclusion criteria, the following data were extracted from the studies: (a) author (s), (b) country, (c) kind of study, (d) population, (e) objective, (f) number 
of morbidity cases, and (g) outcomes. Two reviewers (ATX and AVBV) performed this extraction independently and in the presence of any discrepancy, a more experienced third reviewer (AMAS) performed the data analysis. After the inclusion of selected articles from the databases, a manual search was performed in their reference lists, with the purpose of analyzing possible eligible studies that were not previously identified. This step was followed by the same protocols previously applied.

\subsection{Risk of Bias and Quality Assessment}

The quality assessment of these articles was performed by 2 independent reviewers (ATX and AVBV) using the Standard Quality Assessment Criteria for Assessing Primary Research Articles from a Variety of Fields [7]. It consists of a qualitative and quantitative analysis instrument, which examines the methodological quality of each study included in the review. Each evaluation item receives a score according to the answer; 2 points if the answer is 'yes', 1 point if the answer is 'partial', or 0 points if the answer is 'no'. If any analysis cannot be completed, there is a N/A option (not applicable). The evaluation is divided into the following phases: Total sum $=($ number of "yes" $* 2)+($ number of "partials" * 1), possible total sum $=28-($ number of "N/A" * 2) and Score summarized: total sum/possible total sum. The final percentage indicates the quality and the risk of bias for each study. In this review in the presence of any disagreement, a third reviewer (AMAS) evaluated the studies.

\section{Results}

\subsection{Flow of Included Studies}

Initially, 2150 studies were retrieved in the initial database search, 76 in LILACS, 106 in Web of Science, 1729 in Scopus, and 239 in PubMed, of which 304 were excluded because they were duplicates. After removing duplicates, 1846 studies remained and were screened by reading the titles and abstracts, of which 1667 were excluded. Subsequently, the reviewers read the full texts of the remaining 179 articles, of which 145 were ineligible because (i) they lacked the outcome of interest $(n=120)$ and/or (ii) they did not fully meet the inclusion criteria $(n=25)$. Thus, the electronic search generated 34 studies (Step 1), and 1 study was included via a manual search (Step 2). As a result, 35 articles were included in this review, as detailed in the PRISMA shown in Figure 1.

\subsection{Description of the Studies}

The selected studies were published from 1987 to 2019 and used quantitative $(\mathrm{n}=24)$ and qualitative $(n=11)$ methodologies. Five studies were published before the launch of the GPELF (1997), and 30 studies were published after the launch.

All quantitative articles included in this review are described in Table 1 . The selected studies covered different locations in the Americas: Brazil $(n=21)$, Dominican Republic $(n=5)$, Haiti $(n=6)$, and Guyana $(n=3)$ of which 14 concerned male urogenital disease (hydrocele and lymph scrotum) and 29 covered the topic of lymphoedemas (ADLA and elephantiasis).

Regarding male urogenital disease, 3 of the publications identified were in relation to pathogenesis, 14 were in relation to epidemiology, 3 were in relation to treatment, and 1 was in relation to the repercussions of those clinical manifestations. Regarding lymphoedema, 3 studies addressed the issue of pathogenesis, 13 addressed epidemiology, 8 addressed treatment, and 9 addressed the repercussions of this clinical manifestation.

In the Americas, groups of researchers from the Dominican Republic [8-11], Guyana [12,13], Haiti [14,15], and Brazil [16-18] published a few qualitative studies. They addressed the repercussions of those clinical manifestations, such as quality of life; economic and emotional impact; impact on activities; social support; stigma, and treatment with healthcare providers, beliefs, and traditional practices (Table 2). 


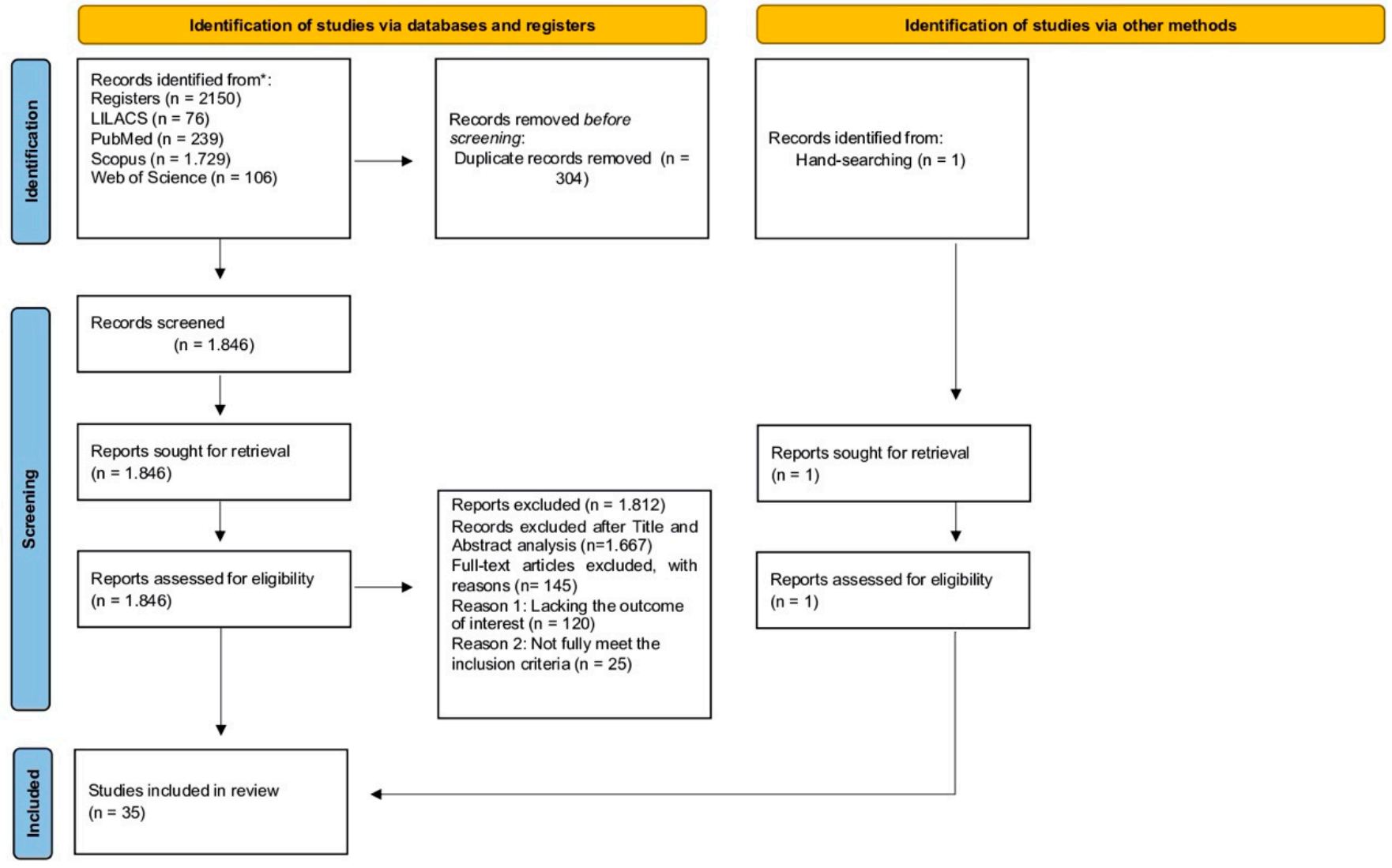

Figure 1. Flow diagram systematic search and review process.

\subsection{Quality Evaluation Criteria}

The scores of the papers ranged from $36 \%$ to $100 \%$ for quantitative methodologies and $40 \%$ to $80 \%$ for qualitative methodologies. The values of $<50 \%$ indicated studies that included less information or presented with incomplete data. Scores ranging from $64 \%$ to $88 \%$ were applied to articles that had the most complete data. In addition, scores from $90 \%$ to $100 \%$ were applied to those with the best clarity of information. Additional File 2 (Tables S1 and S2) present the scores in detail from the quantitative and qualitative studies, respectively. 
Table 1. Details of data extracted from quantitative studies.

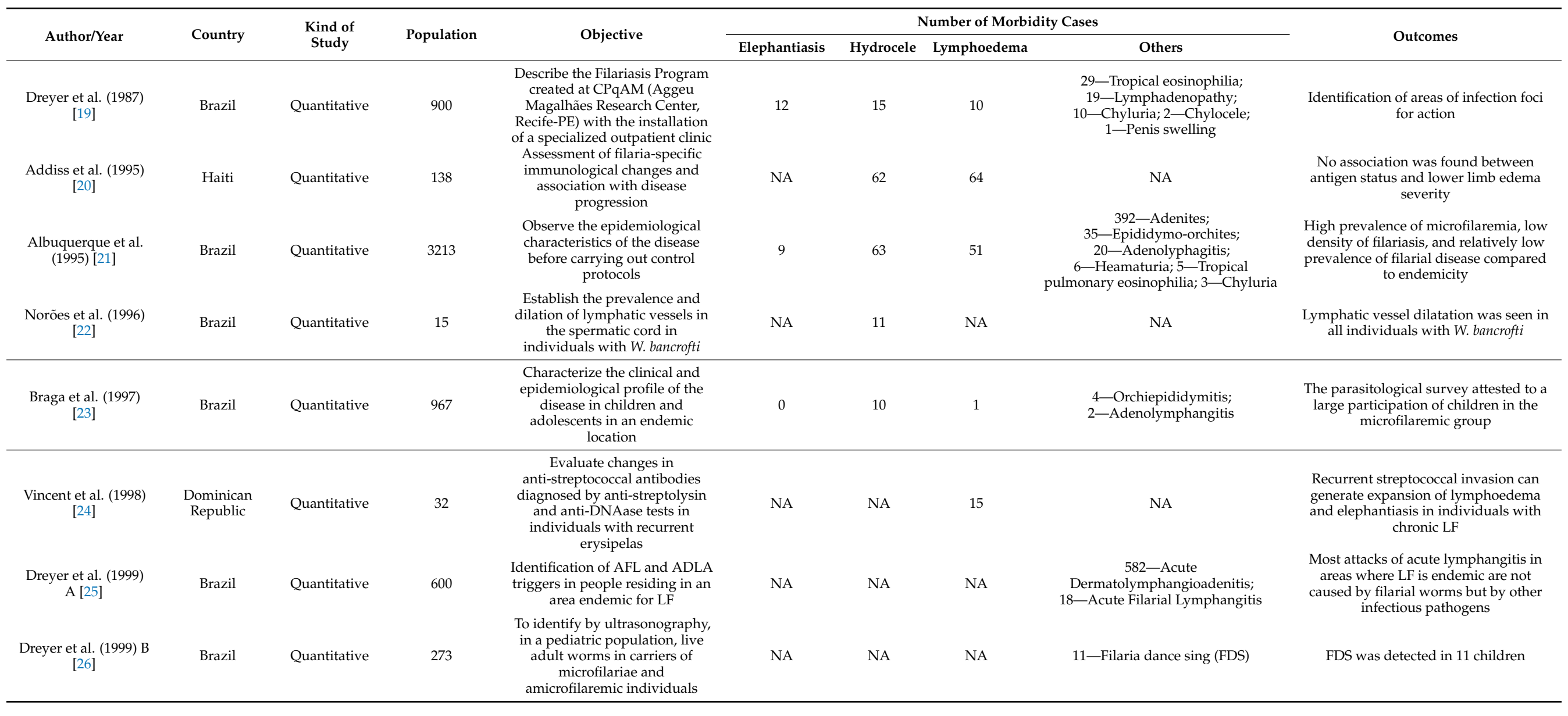


Table 1. Cont.

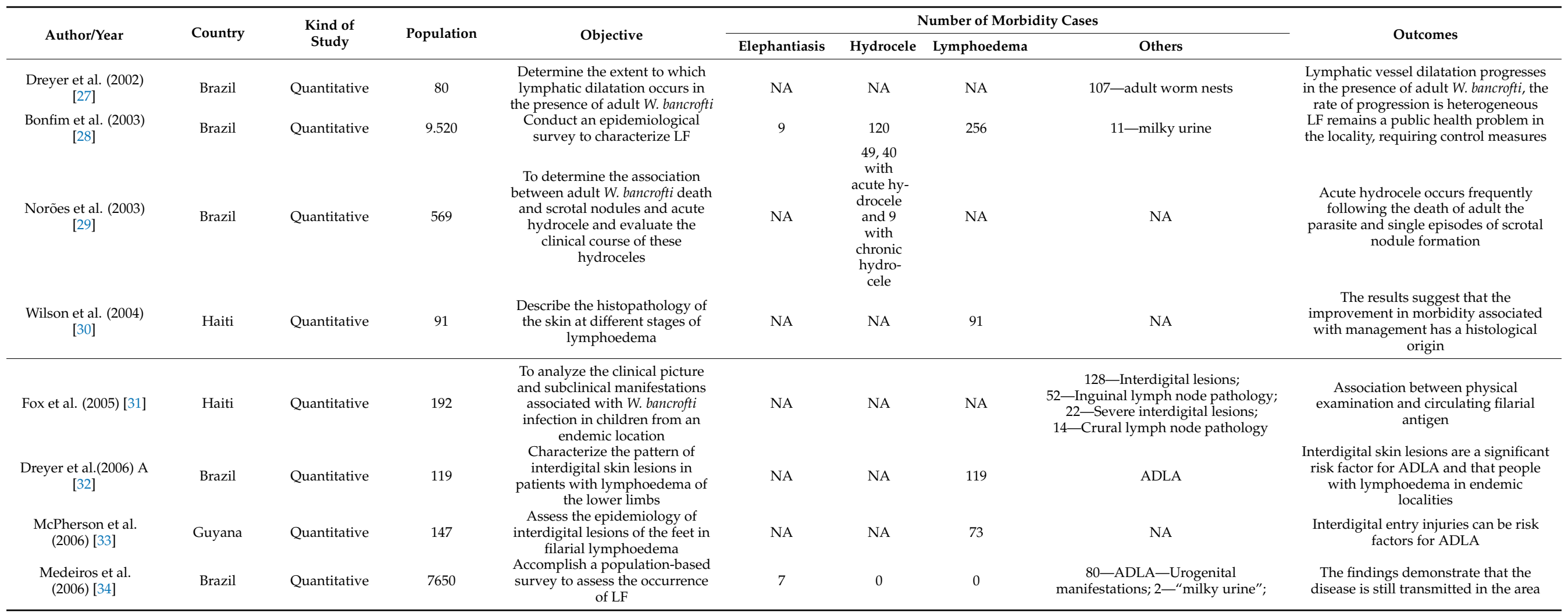


Table 1. Cont.

\begin{tabular}{|c|c|c|c|c|c|c|c|c|c|}
\hline \multirow{2}{*}{ Author/Year } & \multirow{2}{*}{ Country } & \multirow{2}{*}{$\begin{array}{l}\text { Kind of } \\
\text { Study }\end{array}$} & \multirow{2}{*}{ Population } & \multirow{2}{*}{ Objective } & \multicolumn{4}{|c|}{ Number of Morbidity Cases } & \multirow{2}{*}{ Outcomes } \\
\hline & & & & & Elephantiasis & Hydrocele & Lymphoedema & Others & \\
\hline $\begin{array}{l}\text { Freitas et al. (2008) } \\
\qquad[35]\end{array}$ & Brazil & Quantitative & 9465 & $\begin{array}{c}\text { Evaluate the epidemiological } \\
\text { situation of LF in the city of } \\
\text { Belém }\end{array}$ & 0 & 3 & 1 & 18-ADLA; 2-“milky urine" & $\begin{array}{l}\text { Results showed that there was an } \\
\text { interruption in the transmission of the } \\
\text { Belém focus }\end{array}$ \\
\hline $\begin{array}{l}\text { Norões et al. (2009) } \\
{[37]}\end{array}$ & Brazil & Quantitative & 340 & $\begin{array}{l}\text { To analyze intrascrotal nodules } \\
\text { in adult men as a marker of } \\
\text { filarial granuloma in an endemic } \\
\text { location }\end{array}$ & NA & 1 & NA & $\begin{array}{l}\text { 340-nodules; } 1 \text {-adult worm nest } \\
\text { with FDS signal }\end{array}$ & $\begin{array}{l}\text { The results demonstrate great } \\
\text { specificity of intrascrotal nodules with } \\
\text { granuloma in endemic area residents }\end{array}$ \\
\hline $\begin{array}{l}\text { Norões et al. (2010) } \\
{[38]}\end{array}$ & Brazil & Quantitative & 1186 & $\begin{array}{l}\text { Analyze the occurrence of } \\
\text { lymphangiectasia in the scrotal } \\
\text { content, morphology, and } \\
\text { consistency of the testicles and, } \\
\text { recurrence of hydrocele using } \\
\text { the complete excision of the } \\
\text { tunica vaginalis in patients with } \\
\text { hydrocele that }\end{array}$ & NA & 968 & NA & NA & $\begin{array}{l}\text { Fluid from ruptured lymph vessels is } \\
\text { an important component of filarial } \\
\text { hydrocele, the authors advise complete } \\
\text { excision of the hydrocele sac and, when } \\
\text { identified, dilated lymph vessels with } \\
\text { leakage or prone to leakage should be } \\
\text { sutured or excised }\end{array}$ \\
\hline $\begin{array}{l}\text { Rocha et al. (2010) } \\
\text { [39] }\end{array}$ & Brazil & Quantitative & 10.021 & $\begin{array}{l}\text { Present the actions of the } \\
\text { Lymphatic Filariasis Elimination } \\
\text { Program in the city of Olinda-PE }\end{array}$ & 15 & 158 & 15 & 184-ADLA; 2—Chyluria & $\begin{array}{l}\text { Recommendations for evaluation and } \\
\text { follow-up the impact of these actions of } \\
\text { the Lymphatic Filariasis Elimination } \\
\text { Program in the city of Olinda-PE }\end{array}$ \\
\hline $\begin{array}{l}\text { Netto et al. (2016) } \\
{[\text { [40] }}\end{array}$ & Brazil & Quantitative & 23.673 & $\begin{array}{l}\text { Describe the prevalence of } \\
\text { morbidity and its correlation } \\
\text { with filarial infection }\end{array}$ & 0 & 188 & 17 & 519—ADLA; 17—Chyluria & $\begin{array}{l}\text { The findings indicate an association } \\
\text { between reported clinical status and the } \\
\text { rate of infection among people living in } \\
\text { a low endemic area }\end{array}$ \\
\hline $\begin{array}{c}\text { Santana et al. (2016) } \\
\text { [41] }\end{array}$ & Brazil & Quantitative & 35 & $\begin{array}{l}\text { Describe the profile of patients } \\
\text { with lymphedema who were } \\
\text { subjected to Complex } \\
\text { Decongestive Therapy }\end{array}$ & NA & NA & 35 & NA & $\begin{array}{c}\text { The findings provide broad knowledge } \\
\text { about the characteristics of individuals } \\
\text { with lymphoedema who were } \\
\text { subjected to Complex Decongestive } \\
\text { Therapy }\end{array}$ \\
\hline $\begin{array}{l}\text { Soares et al. (2016) } \\
{[\text { [42] }}\end{array}$ & Brazil & Quantitative & 30 & $\begin{array}{l}\text { Assess the effectiveness of } \\
\text { Complex Decongestive Therapy } \\
\text { using alternative inputs and its } \\
\text { impact on the quality of life of } \\
\text { individuals with lymphedema }\end{array}$ & NA & NA & 30 & NA & $\begin{array}{l}\text { The methodology was considered } \\
\text { efficient in reducing lymphoedema, } \\
\text { with positive impacts on the quality of } \\
\text { life of individuals }\end{array}$ \\
\hline
\end{tabular}


Table 2. Details of data extracted from qualitative studies.

\begin{tabular}{|c|c|c|c|c|c|c|c|c|c|}
\hline \multirow{2}{*}{ Author/Year } & \multirow{2}{*}{ Country } & \multirow{2}{*}{$\begin{array}{l}\text { Kind of } \\
\text { Study }\end{array}$} & \multirow{2}{*}{ Population } & \multirow{2}{*}{ Objective } & \multicolumn{4}{|c|}{ Number of Morbidity Cases } & \multirow{2}{*}{ Outcomes } \\
\hline & & & & & Elephantiasis & Hydrocele & Lymphoedema & Others & \\
\hline $\begin{array}{l}\text { Coreil et al. } \\
\text { (1998) [15] }\end{array}$ & Haiti & Qualitative & 29 & $\begin{array}{l}\text { Describe the impact of } \\
\text { lymphoedema on } \\
\text { women's lives }\end{array}$ & 29 & NA & 29 & NA & $\begin{array}{l}\text { Morbidity interferes } \\
\text { socioeconomically in } \\
\text { women's lives }\end{array}$ \\
\hline $\begin{array}{l}\text { McPherson et al. } \\
\text { (2003) [12] }\end{array}$ & Guyana & Qualitative & 14 & $\begin{array}{l}\text { Describe, in individuals } \\
\text { with lymphoedema, the } \\
\text { impact on quality of life } \\
\text { after inclusion of a } \\
\text { hygiene and skin care } \\
\text { regimen }\end{array}$ & NA & NA & 14 & NA & $\begin{array}{l}\text { The care regimen was } \\
\text { found to be effective in } \\
\text { improving the quality of } \\
\text { life of individuals with } \\
\text { lymphoedema }\end{array}$ \\
\hline $\begin{array}{l}\text { Coreil et al. } \\
\text { (2006) [14] }\end{array}$ & Haiti & Qualitative & $\begin{array}{l}\text { Five } \\
\text { support } \\
\text { groups }\end{array}$ & $\begin{array}{l}\text { Assess the process of } \\
\text { indigenization in } \\
\text { support groups for } \\
\text { women with filarial } \\
\text { morbidity }\end{array}$ & NA & NA & NA & NA & $\begin{array}{l}\text { Creation of support } \\
\text { groups with various } \\
\text { activities focused on } \\
\text { more technical terms } \\
\text { related to LF and also on } \\
\text { broader themes, such as } \\
\text { religion, spirituality, } \\
\text { handicrafts, and others }\end{array}$ \\
\hline $\begin{array}{l}\text { Person et al. } \\
\text { (2006) [8] }\end{array}$ & $\begin{array}{l}\text { Dominican } \\
\text { Republic }\end{array}$ & Qualitative & 28 & $\begin{array}{l}\text { To observe health } \\
\text { beliefs and self-care } \\
\text { habits in women with } \\
\text { lymphoedema }\end{array}$ & NA & NA & 28 & NA & $\begin{array}{l}\text { The findings indicate that } \\
\text { family, friends, and } \\
\text { cultural habits influence } \\
\text { the disease model }\end{array}$ \\
\hline $\begin{array}{l}\text { Person et al. } \\
\text { (2007) A [10] }\end{array}$ & $\begin{array}{l}\text { Dominican } \\
\text { Republic }\end{array}$ & Qualitative & 28 & $\begin{array}{l}\text { Understanding the } \\
\text { psychosocial and health } \\
\text { consequences } \\
\text { associated with leg } \\
\text { lymphoedema among } \\
\text { women }\end{array}$ & NA & NA & 28 & NA & $\begin{array}{l}\text { The women's quality of } \\
\text { life varied depending on } \\
\text { changes in their health } \\
\text { status, but the physical } \\
\text { limitations were not } \\
\text { always related to the } \\
\text { severity of the symptoms }\end{array}$ \\
\hline
\end{tabular}


Table 2. Cont.

\begin{tabular}{|c|c|c|c|c|c|c|c|c|c|}
\hline \multirow{2}{*}{ Author/Year } & \multirow{2}{*}{ Country } & \multirow{2}{*}{$\begin{array}{l}\text { Kind of } \\
\text { Study }\end{array}$} & \multirow{2}{*}{ Population } & \multirow{2}{*}{ Objective } & \multicolumn{4}{|c|}{ Number of Morbidity Cases } & \multirow{2}{*}{ Outcomes } \\
\hline & & & & & Elephantiasis & Hydrocele & Lymphoedema & Others & \\
\hline $\begin{array}{l}\text { Person et al. } \\
\text { (2007) B [9] }\end{array}$ & $\begin{array}{l}\text { Dominican } \\
\text { Republic }\end{array}$ & Qualitative & 28 & $\begin{array}{l}\text { Observe the social } \\
\text { connection among } \\
\text { women with filarial } \\
\text { lymphoedema }\end{array}$ & NA & NA & 28 & NA & $\begin{array}{l}\text { Social disconnection can } \\
\text { increase the negative } \\
\text { effects of living with this } \\
\text { morbidity }\end{array}$ \\
\hline $\begin{array}{l}\text { Person et al. } \\
\text { (2009) [11] }\end{array}$ & $\begin{array}{l}\text { Dominican } \\
\text { Republic }\end{array}$ & Qualitative & 104 & $\begin{array}{l}\text { Investigate women } \\
\text { with lymphoedema } \\
\text { who suffer from } \\
\text { disease-related stigma }\end{array}$ & NA & NA & 104 & NA & $\begin{array}{l}\text { Women described that } \\
\text { they suffer from criticism } \\
\text { and are isolated by the } \\
\text { community, health } \\
\text { professionals, and even } \\
\text { by friends and relatives, } \\
\text { in addition to being } \\
\text { constantly denied access } \\
\text { to education and work }\end{array}$ \\
\hline Tyrell (2013) [13] & Guyana & Qualitative & 100 & $\begin{array}{l}\text { To analyze the } \\
\text { socioeconomic impact } \\
\text { of LF in Guyana }\end{array}$ & NA & NA & NA & NA & $\begin{array}{l}\text { Patients with chronic LF } \\
\text { face significant impacts } \\
\text { related to emotional and } \\
\text { financial issues }\end{array}$ \\
\hline $\begin{array}{l}\text { Pedrosa et al. } \\
\text { (2019) [16] }\end{array}$ & Brazil & Qualitative & 25 & $\begin{array}{l}\text { To analyze the influence } \\
\text { of unilateral lower limb } \\
\text { lymphoedema on } \\
\text { functionality and } \\
\text { quality of life }\end{array}$ & NA & NA & 25 & NA & $\begin{array}{l}\text { Individuals with lower } \\
\text { unilateral lymphoedema } \\
\text { suffer negative impacts } \\
\text { on quality of life }\end{array}$ \\
\hline
\end{tabular}




\section{Discussion}

More focus on the second pillar of the GPELF program, morbidity management, is increasingly required. Valid and reliable information regarding the number of people affected in each of the most frequent clinical expressions, the treatment approach instituted, the structure of care services offered, responses to treatments, disability and the impact of disease, and patient and community needs are important in the assessment and planning in endemic areas to ensure the best management for the prevention and alleviation of lymphatic filariasis-related disability. As a strategy for use in structuring the assistance of filarial morbidity, the GPELF suggests the identification of the number of individuals affected by the disease in areas where MDA is implemented.

This review identified insufficient data regarding the number of cases of morbidity in endemic countries. No population surveys were carried out in any of the countries studied, which is indicative of under-reporting, which is a trend that had already been highlighted in other endemic areas [4]. There are also gaps in studies with a robust methodology that can be "replicable" for treatment assessment, such as physical therapy for lymphedema treatment and the surgical technique used for the treatment of hydrocele. A small number of publications related to properly structured operational and implementation investigations, including community-based and applied research, which is essential for building a solid foundation on which effective interventions can be designed and carried out as suggested by WHO [4].

In this review, two major clinical manifestations were addressed: male urogenital disease (hydrocele and lymph scrotum) and lymphoedema (including ADLA and elephantiasis). Due to the non-uniformity of the methodologies used in the addressed studies, comparison of the data was limited and, therefore, we chose to present the information in similar topics referring to these manifestations.

\subsection{Male Urogenital Disease: Hydrocele and Lymph Scrotum}

Although hydrocele and lymph scrotum exert a significant impact on public health and men's lives in endemic areas, many gaps in the knowledge regarding these issues mean that certain topics still remain unclear, such as ideal management, intervention costs and their complications, and economic, social, emotional, and sexual repercussions.

\subsection{Pathogenesis}

The biggest contributions related to the topic of male urogenital disease manifestations came from Brazilian authors and included: (i) longitudinal ultrasonographic measurements of the intrascrotal lymphatic vessel diameter at the site of living adult $W$. bancrofti observed that diameter increased in a high percentage of adult worm nests [27]; (ii) no significant difference was observed in the rate of scrotal lymphatic vessel dilatation among men who were treated or not treated with antifilarial drugs (diethylcarbamazine-DEC) [29]; (iii) the identification rate of hydrocele was higher in men who received DEC than in untreated men, and during the follow-up period, this manifestation did not resolve within 18 months or continued to increase in size [29]; (iv) an important association between filarial infection and the inadequate surgical and clinical management of hydrocele was identified as a risk factor for lymph scrotum [36]. All of this information corroborates the findings of previous studies that concerned residents of areas where filariasis is endemic that show that the primary lesion in these populations is not an obstruction but lymphatic vessel dilatation [44,45]; other studies have demonstrated that filarial hydrocele is triggered by the death of an adult worm, which produces an inflammatory nodule that occludes the lymphatic vessel [46-48]. Regarding lymph scrotum, a dermatological manifestation of pathological lymphatic drainage, which is an unusual urological clinical presentation of LF, may be identified following surgery for chylocele or hydrocele [49]. 


\subsection{Epidemiology}

There is no real estimate of the number of men affected by hydrocele in endemic areas, but there is a strong association of its prevalence with that of microfilaremia (MF), and the prevalence of hydrocele increases with age [50,51]. Studies in Haiti show that in men with hydrocele, there is a high percentage of active W. bancrofti infection [20]. Additionally, these studies show that in areas where nearly half of the population has LF, $25 \%$ of the males have genital lymphoedema and scrotal damage due to the disease (hydrocele) and that this is often hidden and unreported [43].

In Brazil, a 5.5\% prevalence of hydrocele was found among 1177 individuals, $26 \%$ of the subjects with hydrocele were MF carriers [21], and in children, the prevalence of infection was $6.4 \% ; 3.8 \%$ of children in the study were identified as having hydrocele, with a predominance in the age group of 10-14 years [23]. Ultrasonographic studies were important in identifying hydrocele in microfilaremic men [22] and children [26]. Some studies presented percentage rates of participants who reported a complaint ranging from 1.1 to $1.57 \%[26,28,34,39,40]$, and another study showed that only isolated cases were identified [35].

\subsection{Repercussions of Clinic Manifestation}

Aguiar-Santos et al., 2009 [36], identified that in all evaluated cases of lymph scrotum, there was a report of the occurrence of ADLA due to secondary bacterial infection that was constant and repeated. This medical issue causes the continuous drainage of milky secretion; affected individuals are often prevented from engaging in work or leisure activities, changes may occur to their social interactions, and they may have issues regarding sexual intercourse. They may also experience symptoms of depression. In this review, it was observed that a small number of studies exist beyond the biological scope that has focused on the assessment of the repercussions of male urogenital manifestations of FL in the social, emotional, and sexual spheres in the affected population.

\subsection{Treatment}

It is emphasized that the treatment with DEC for individuals when they present microfilaremia may be of fundamental importance for the control of transmission, highlighting the fact that these individuals continue to live in endemic areas, and are at risk of reinfection [36]. A retrospective study in Brazil emphasized that the best way to monitor the effectiveness of antifilarial drugs is the combined use of ultrasound and physical examination to monitor the development of scrotal nodules [37].

Regarding hydrocele surgery, a selected paper concluded that with the intent to avoid hydrocele recurrence and testicular damage, a specific surgical technique that involves the complete excision of the tunica vaginalis and meticulous attention to cauterization of the edges and suturing offers the best cosmetic and functional result with a lower risk of lymph scrotum [38]. Once the lymph scrotum is identified, the approach to this morbid condition is based on conservative measures that avoid its progression. These measures consist of local hygiene care, in the same manner as that proposed for lymphoedema in the limbs, and antibiotic prophylaxis using benzathine penicillin. However, in some cases, surgical reconstruction has been shown to be efficient, considering that this chronic disease is of an irreversible nature [36].

\subsection{Lymphoedema-ADLA and Elephantiasis}

One of the most distressing clinical presentations of lymphatic dysfunction in LF in endemic areas is advanced lymphoedema or elephantiasis which for reasons that are poorly understood, affect women more frequently than men in many parts of the world, including in the Americas $[15,20]$. Lymphoedema is a chronic condition that is not curable at present, but may be alleviated by the appropriate management of ADLA; if ignored, it can progress and become difficult to manage. 


\subsection{Pathogenesis}

Dreyer et al., 1999 [25], reported two distinct acute syndromes accompanied by lymphangitis; one is called acute filarial lymphangitis (AFL), which is caused by the death of adult worms, and usually, it is asymptomatic or has a mild clinical course and rarely causes residual lymphoedema. The second syndrome is called ADLA, which is not caused by filarial worms per se, but probably results from a secondary bacterial infection. The majority of patients with ADLA reported experiencing a recurrence of the attacks which are considered to be the main risk factor for the development of lymphoedema and elephantiasis, as previously described $[52,53]$ There is clinical evidence that AFL precedes the onset of ADLA in a portion of the population, suggesting that LF is a risk factor for secondary infections [32].

Studies carried out in Haiti and Guyana showed that severe interdigital lesions were associated with laboratory evidence of filarial infection [31] and that the number of lesions was the strongest predictor of the frequency of ADLA [33]. Additionally, studies in the Dominican Republic concluded that about half of the acute episodes identified were caused by, or associated with, infections with group A hemolytic streptococci [24].

\subsection{Epidemiology}

Few prevalence studies that were representative of the population at risk in endemic areas of the Americas were identified; some studies gave a small estimate of the number of those affected and their significance as a public health problem [19,21,23,28,32]. It was observed that there is an underestimation of the number of patients with lymphoedema, which is largely underestimated in areas still endemic, as well as in those areas that have already achieved transmission disruption.

In Brazil, a variation in the frequency of lymphoedema was also observed according to the prevalence of filarial infection in the study area and characteristics of the population studied (age and sex), in addition to the method of collection, whether by clinical examination or reported complaint. In general, the frequency of lymphoedema is higher in women, it increases with age, and in surveys that concerned reported complaints, ADLA citation is quite high $[21,23,28,34,35,39,40]$. ADLA incidence was associated with the lymphoedema stage, and the number of interdigital skin lesions detected by the examining physician [32].

In Haiti, in specific hyperendemic zones, estimates suggest that even $5 \%$ of the Haitian population suffers from lymphoedema associated with LF. Many women and girls suffer from leg elephantiasis [43].

In patients with lymphoedema, a high occurrence of comorbidities was also identified, with the most frequent being obesity, hypertension, and diabetes [41]. These data suggest that care services for patients with filarial morbidity include specialized care that also aims to address these problems [54].

\subsection{Repercussions of Clinic Manifestation}

Our findings regarding the repercussions of lymphoedema are all qualitative studies published regarding endemic countries after the launch of the GPELF. No reports were identified in the areas of America that have already eliminated filariasis (Trinidad, Suriname, and Costa Rica).

Several publications indicate that morbidity caused by LF has dramatic social, economic, and emotional consequences, particularly for women, who are over 10 times more likely to have elephantiasis of the leg than men [55-59]. Having knowledge of the consequences of this morbidity in these various aspects will support countries in structuring assistance services to provide care in a holistic way, as is the goal established in the GPELF.

Qualitative studies carried out in the Dominican Republic and Guyana have made important contributions towards investigating how women from different cultures with lymphoedema experience stigma and its consequences [11]. Some women felt that speaking about these practices would be uncharitable and that the burden they faced was a test from God and described a cultural practice of not talking about or belittling someone 
with a disease or disability because to do so would put one at risk of getting the same condition. For some women, it was the quantity or burden of stigma experiences that meant they had ineffective management or coping capabilities that created distressing personal consequences. Poverty, poor access to healthcare resources, limited education, and diminished social support challenged the coping strategies of many women and exacerbated the negative consequences of lymphoedema-related stigma [8-11].

For these women, indigenous healers have influence over the physical, mental, spiritual, and supernatural properties of illness for initial care, and only when indigenous treatments proved to be ineffectual did they seek care from trained healthcare providers [8]. In other endemic areas not located in the Americas, traditional practices for lymphoedema include herbal preparations which are smeared on the affected limb, scarification or cutting the skin, analgesics bought from local drug peddlers [60-62], and inappropriate treatments, such as diuretic therapy [63].

Women described a spectrum of consequences associated with their lymphoedema, but physical, functional, and psychological limitations were not always associated with the severity of lymphoedema [10]. The confluence of chronic and acute illness with the severity of lymphoedema leads women to rely on others for social support. Women described complications regarding aging, disability, reduced social networks, and the inability to adhere to cultural scripts as contributors to disrupted social connectedness. Most women resorted to self-prescribing injectable, oral, or topical antibiotics along with oral analgesics without medical supervision [9].

An intervention study was conducted in Guyana that concerned patients with lymphoedema that was clinically confirmed and classified by the Dreyer scale [64] The patients were interviewed regarding their disease history and current acute attack rates, they also answered the questionnaire about current knowledge, attitudes, and practices (KAP) and completed a Dermatology Life Quality Index (DLQI). After this, interventions were put in place, which included education and training of a local nurse, individual patient education, and access to appropriate treatments. This low-cost intervention study had a significant impact on the quality of life of patients with a reduction in the number of acute attacks, leading to the increased ability to work and perform activities of daily living [12].

Tyrell and colleagues, 2013 [13] explained that there is a necessity for the establishment of support groups where issues and problems can be discussed in an atmosphere of empathetic understanding with the use of social networks and services, such as Skype and Google. The number of lymphoedema and hydrocele patients in lymphatic filariasis endemic communities are usually under-reported, which consequently affects their management. Therefore, an innovative tool can give accurate information on morbidity cases in real-time in Ghana and can also reduce the under-reporting of cases is need [65].

In a community located about $30 \mathrm{~km}$ west of Port-au-Prince (Haiti) where the prevalence of microfilaremia was 33\% and about one-half of the population was infected with $W$. bancrofti, researchers described the process of indigenization within peer support groups for Haitian women living with chronic physical impairment of LF. Five support groups established in a coastal community were studied over a period of 3 years to understand the adaptation of the Western illness support group model to the local cultural milieu. Unlike most support groups in affluent settings, the Haitian women showed minimal interest in talking about illness-related issues. The groups developed a distinctly Haitian style characterized by an emphasis on religion and spirituality, artistic and expressive components, and the acquisition of practical skills that offer income-generating opportunities. Members directed the greatest energy toward developing microenterprise activities [14]. In another study in Leogane, Haiti, researchers investigated the ethnographic context of filarial elephantiasis among women and focused on explanatory models of the illness, the impact of the disease on women's lives, and the difficulties patients experienced in following a therapeutic regimen provided at a local hospital [15].

The results indicate that traditional understanding and treatment for the disease are prevalent in the community. These studies show that the pattern of adaptation is discussed 
in terms of indigenous traditions of mutual aid in rural Haiti, the compelling material needs of families living in stark poverty, and the ongoing challenge of coping with political and economic insecurity. Women's lives are substantially burdened both socially and economically by the physical impairment of elephantiasis, most notably by the loss of income due to restrictions on mobility. The degree of social discrimination encountered varies by the timing of the onset of symptoms in one's life course. Difficulties encountered with the physical therapy regimen included the maintenance of the compressive bandage and the availability of suitable footwear.

Three studies were carried out in Brazil focusing on sequelae in patients with chronic lymphatic filariasis. Dreyer, Norões, and Mattos, 2006 [18], developed a care program that could equip lymphoedema patients with the skills, motivation, and enthusiasm to sustain an effective, low-cost, and convenient self-care to prevent episodes of ADLA and milky urine in the case of chyluria carriers. This innovative care approach was called Hope Clubs. For people with elephantiasis, recovery of full "citizenship" and human dignity can be a powerful strategy for overcoming prejudice and stimulating socially responsible action. The synergy — and even magic — that is created when patients come together to share their lives and experiences in Hope Club meetings creates the possibility for the multiplication of knowledge. Hope Clubs are a powerful instrument for generating action for the social inclusion of people with elephantiasis [17]. In a group of 25 patients with lymphoedema, quality of life was compromised in all domains of the SF-36; they were principally affected in the domains of functional capacity $(45.4 \pm 25.9)$, emotional aspects $(36.0 \pm 42.9)$, and limitations due to physical aspects $(25.0 \pm 31.4)$. Those studies point to a necessity for the establishment of support groups where issues and problems can be discussed in an atmosphere of empathetic understanding [13].

\subsection{Treatment}

There is no proven drug treatment for lymphoedema. Management aims to reduce or delay the progression of swelling and prevent associated infection [63].

In Brazil, a study highlighted some points regarding the treatment of ADLA and LFA. The use of DEC, an antifilarial drug, did not stop or shorten the duration of acute episodes of either ADLA or LFA and did not prevent the recurrence of ADLA, nor did it stop disease progression, although the majority of the patients with elephantiasis who were referred had been previously treated with up to six full courses of DEC [25]. On the other hand, there is evidence that persistent local hygiene and the cure and prevention of entry lesions with antiseptics and topical antibiotic/antimycotic salves can stop ongoing attacks and completely prevent their recurrence [66]. In advanced cases, it may be necessary to combine such topical treatments with antibiotic prophylaxis to achieve this goal. Additionally, to prevent the recurrence of ADLA and progression to elephantiasis, it is essential that patients with lymphoedema are able to promptly identify and treat interdigital skin lesions. Studies indicate that among patients coming to the clinic for the first time, very few were aware that they had interdigital skin lesions, or if they were aware, they did not recognize the lesions as abnormal [32]. Physiotherapy using the edema reduction technique called Complex Decongestive Therapy (CDT), which aims to promote lymphatic return and a reduction in frequent pain, was shown to be effective in reducing and controlling lymphoedema and had a positive impact in some studies, causing participants in intervention groups to provide more positive answers to questionnaires regarding quality of life in physical and environmental domains [41,42].

In the Dominican Republic, in a study that concerned the response of anti-streptolysin 0 titer and anti-DNAase B antibodies in the 28 erysipelas cases enrolled, benzathine penicillin was highly used and intramuscular injection usually brought an almost dramatic relief for the patients [24]. In Guyana, a study analyzed the impact on the quality of life that education and the introduction of organized care had on lymphoedema patients after they were individually educated on lymphatic filariasis, given appropriate advice on how to manage their lymphoedema, educated on the importance of hygiene, skin care, and 
elevation, and taught simple exercises to encourage lymph drainage. Treatment was given from a formulary of antibiotics (Penicillin) (in the case of a current acute attack), antiseptics (potassium permanganate), and topical creams (Bacitracin ointment and Miconazole 2\%). Each patient was given a tube of a topical antibacterial and antifungal cream if clinically indicated, and a patient education leaflet. The Dermatology Life Quality Index, a questionnaire that is an accurate way of assessing the effect skin disease has on quality of life was repeated 1 year later and improved for all patients, and the number of reported acute attacks was reduced. This study shows that in this community, with only a very limited input of time and financial resources, a change/introduction in the treatment regime can have a beneficial impact on patients with lymphoedema within a year [12].

In Haiti, the effect of basic lymphoedema management (hygiene, skin care, and lower limb movement and elevation) was investigated via biopsy specimens collected during the follow-up of 27 patients. Biopsies showed reductions in perivascular mononuclear infiltrate in the superficial dermis, perivascular fibrosis in the deep dermis, and periadnexal mononuclear infiltrate suggesting clinical improvement [30]. In 2012, a morbidity management program was established based on a series of training programs and provided the requisite knowledge to appreciate the pathophysiology associated with LF, along with didactic and hands-on training involving modified protocols encompassing Complete Decongestive Therapy and basic skin and wound care principles. The technicians taught the patients proper skin care and hygiene and provided modified protocols involving manual lymph drainage, diaphragmatic breathing, compression, patient education, and basic wound care. Overall, the results were impressive including, but not limited to significant reductions in limb volume; improved skin integrity; independence with self-care; enhanced quality of life; improvements in functional abilities and activities of daily living; the ability to return to work; and reduced perceptions of social stigma [43].

In this review study, there were limitations in comparing the results found, particularly due to the variety of methodologies used by researchers. Despite the increase in the number of studies after the launch of the GPEFL, it was observed that the information contained in the publications is still insufficient to identify the number of people affected, the effectiveness of treatments, and the structuring of services to accommodate the cases identified in the Americas.

\section{Conclusions}

In this review, we sought to analyze publications related to the handling of filarial morbidity, particularly male urogenital manifestations and lymphoedema, as the most frequent sequelae observed in endemic areas. The findings were limited to publications from American countries where these diseases are still considered endemic: Brazil, Guyana, Haiti, and the Dominican Republic, and it also aimed to identify the conduction of the GPELF morbidity pillar in these countries, its epidemiology, treatment used, economic and social consequences, psychological and care structures already in place, as there are gaps in this knowledge. This knowledge is essential if the WHO Global Control of Lymphatic Filariasis Validation is to be achieved. Current burden estimates are limited in reliability because of the paucity of survey data available on which to base estimates of the total number of cases. In order to develop more robust estimates of the burden of filarial morbidity, there needs to be a coordinated effort to conduct population-based surveys.

Thus, to prevent suffering and disability in those who already have chronic manifestations of lymphatic filariasis, as recommended by the GPELF, it is necessary that countries of the Americas, through a coordinated effort from health services and researchers, develop strategies that aim to address the pillar of morbidity through the implementation and maintenance of services intended for this purpose.

Supplementary Materials: The following are available online at https:/ / www.mdpi.com/article/10 .3390/ijerph19010316/s1, Table S1: Quality evaluation of the included quantitative studies, Table S2: Quality evaluation of the included qualitative studies. 
Author Contributions: Conceptualization, A.M.A.-S. and Z.M.M.; methodology, A.T.X., A.V.B.V. and Z.M.M.; software, C.V.B.; validation, M.d.F.C.L.; formal analysis, G.S.N.B.; investigation, A.T.X.; resources, A.V.B.V.; data curation, Z.M.M.; writing-original draft preparation, A.M.A.-S.; writingreview and editing, G.S.N.B.; visualization, Z.M.M.; supervision, M.d.F.C.L.; project administration, Z.M.M.; funding acquisition, A.M.A.-S. All authors have read and agreed to the published version of the manuscript.

Funding: This research was funded by the Pan American Health Organization/Ministry of Health Brazil, grant number SCON2021-00098.

Institutional Review Board Statement: Not applicable.

Informed Consent Statement: Not applicable.

Data Availability Statement: The data presented in this study are available in the present article and its Supplementary Materials reported above.

Conflicts of Interest: The authors declare no conflict of interest.

\section{References}

1. World Health Organization. Global programme to eliminate lymphaticfilariasis: Progress report, 2019. Wkly. Epidemiol. Rec. 2020, 95, 509-524.

2. Gordon, S.; Melrose, W.; Warner, J.; Buttner, P.; Ward, L. Lymphatic Filariasis: A Method to Identify Subclinical Lower Limb Change in PNG Adolescents. PLoS Negl. Trop. Dis. 2011, 5, e1242. [CrossRef]

3. Melrose, W.D. Lymphatic filariasis: New insights into an old disease. Int. J. Parasitol. 2002, 32, 947-960. [CrossRef]

4. WHO. Ending the Neglect to Attain the Sustainable Development Goals-Aroad Map for Neglected Tropical Diseases 2021-2030; World Health Organization: Geneva, Switzerland, 2020; Volume 202, p. 55.

5. Turner, H.C. Health economic analyses of the Global Programme to Eliminate Lymphatic Filariasis. Int. Health 2021, 13, S71-S74. [CrossRef] [PubMed]

6. Page, M.J.; McKenzie, J.E.; Bossuyt, P.M.; Boutron, I.; Hoffmann, T.C.; Mulrow, C.D.; Shamseer, L.; Tetzlaff, J.M.; Akl, E.A.; Brennan, S.E.; et al. The PRISMA 2020 statement: An updated guideline for reporting systematic reviews. BMJ 2021, 372, n71. [CrossRef] [PubMed]

7. Kmet, L.M.; Lee, R.C.; Cook, L.S. Standard quality assessment criteria for evaluating primary research papers from a variety of fields. Edmont. Alta. Herit. Found. Med. Res. 2004, 1-22. Available online: https://www.ihe.ca/advanced-search/standardquality-assessment-criteria-for-evaluating-primary-research-papers-from-a-variety-of-fields (accessed on 10 December 2021).

8. Person, B.; Addiss, D.G.; Bartholomew, L.K.; Meijer, C.; Pou, V.; van den Borne, B. Health-seeking behaviors and self-care practices of Dominican women with lymphoedema of the leg: Implications for lymphoedema management programs. Filaria J. $2006,5,13$. [CrossRef]

9. Person, B.; Bartholomew, L.K.; Addiss, D.; van den Borne, B. Disrupted social connectedness among Dominican women with chronic filarial lymphedema. Patient Educ. Couns. 2007, 68, 279-286. [CrossRef]

10. Person, B.; Addiss, D.; Bartholomew, L.K.; Meijer, C.; Pou, V.; Gonzálvez, G.; van den Borne, B. A qualitative study of the psychosocial and health consequences associated with lymphedema among women in the Dominican Republic. Acta Trop. 2007, 103, 90-97. [CrossRef]

11. Person, B.; Bartholomew, L.K.; Gyapong, M.; Addiss, D.G.; van den Borne, B. Health-related stigma among women with lymphatic filariasis from the Dominican Republic and Ghana. Soc. Sci. Med. 2009, 68, 30-38. [CrossRef] [PubMed]

12. McPherson, T. Impact on the quality of life of lymphoedema patients following introduction of a hygiene and skin care regimen in a Guyanese community endemic for lymphatic filariasis: A preliminary clinical intervention study. Filaria J. 2003, 2, 1. [CrossRef] [PubMed]

13. Tyrell, E. Socioeconomic burden of lymphatic filariasis in Georgetown, Guyana. Trop. Med. Int. Health 2013, 18, 152-158. [CrossRef] [PubMed]

14. Coreil, J.; Mayard, G. Indigenization of Illness Support Groups in Haiti. Hum. Organ. 2006, 65, 128-139. [CrossRef]

15. Coreil, J.; Mayard, G.; Louis-Charles, J.; Addiss, D. Filarial elephantiasis among Haitian women: Social context and behavioural factors in treatment. Trop. Med. Int. Health 1998, 3, 467-473. [CrossRef]

16. Pedrosa, B.C.D.S.; Maia, J.N.; Ferreira, A.P.D.L.; Araújo, M.D.G.R.D.; Montenegro, E.J.N.; Da Silva, F.L.; De Castro, C.M.M.B.; Andrade, M.D.A. Functionality and quality of life of patients with unilateral lymphedema of a lower limb: A cross-sectional study. J. Vasc. Bras. 2019, 18, e20180066. [CrossRef]

17. Mattos, D.; Dreyer, G. Elefantíase em área de filariose bancroftiana: O lado humano da doença. Rev. Patol. Trop. J. Trop. Pathol. 2007, 35, 117-124. [CrossRef]

18. Dreyer, G.; Norões, J.; Mattos, D. Hope Clubs as adjunct therapeutic measure in bancroftian filariasis endemic áreas. Rev. Soc. Bras. Med. Trop. 2006, 39, 365-369. [CrossRef]

19. Dreyer, G. Filariasis programme-Recife-Brazil. Memórias Inst. Oswaldo Cruz 1987, 82, 359-360. [CrossRef] 
20. Addiss, D.G.; Dimock, K.A.; Eberhard, M.L.; Lammie, P.J. Clinical, Parasitologic, And Immunologic Observations of Patients with Hydrocele and Elephantiasis in an Area with Endemic Lymphatic Filariasis. J. Infect. Dis. 1995, 171, 755-758. [CrossRef] [PubMed]

21. Albuquerque, M.; Marzochi, M.; Sabroza, P.; Braga, M.; Padilha, T.; Silva, M.C.; Silva, M.R.; Schindler, H.; Maciel, M.; Souza, W.; et al. Bancroftian filariasis in two urban areas of Recife, Brazil: Pre-control observations on infection and disease. Trans. R. Soc. Trop. Med. Hyg. 1995, 89, 373-377. [CrossRef]

22. Noroes, J.; Addiss, D.; Santos, A.; Mereidos, Z.; Coutinho, A.; Dreyer, G. Ultrasonigraphic Evidence of Abnormal Lymphatic Vessels in Young Men with Adult Wuchereria Bancrofti Infection in the Scrotal Area. J. Urol. 1996, 156, 409-412. [CrossRef]

23. Braga, C.; Albuquerque, M.D.F.M.D.; Schindler, H.; Rezende, A.; Maciel, A.; e Silva, M.C.M.; Furtado, A.; Carvalho, A.B.; Lapa, T.; Ximenes, R.A.D.A. Epidemiological pattern of limphatic filariasis in children living in endemic areas. J. Pediatr. 1997, 73, 95-100. [CrossRef] [PubMed]

24. Vincent, A.L.; Ureña Rojas, C.A.; Ayoub, E.M.; Ottesen, E.A.; Harden, E.G. Filariasis and erisipela in Santo Domingo. J. Parasitol. 1998, 84 (Suppl. 4), 557-561. [CrossRef]

25. Dreyer, G.; Medeiros, Z.; Netto, M.J.; Leal, N.C.; De Castro, L.G.; Piessens, W.F. Acute attacks in the extremities of persons living in an area endemic for bancroftian filariasis: Differentiation of two syndromes. Trans. R. Soc. Trop. Med. Hyg. 1999, 93, $413-417$. [CrossRef]

26. Dreyer, G.; Norões, J.; Addiss, D.; Santos, A.; Medeiros, Z.; Figueredo-Silva, J. Bancroftian filariasis in a paediatric population: An ultrasonographic study. Trans. R. Soc. Trop. Med. Hyg. 1999, 93, 633-636. [CrossRef]

27. Dreyer, G.; Addiss, D.; Roberts, J.; Norões, J. Progression of lymphatic vessel dilatation in the presence of living adult Wuchereria bancrofti. Trans. R. Soc. Trop. Med. Hyg. 2002, 96, 157-161. [CrossRef]

28. Bonfim, C.; Lessa, F.; Oliveira, C.; Evangelista, M.J.; Santo, M.D.E.; Meireles, E.; Pereira, J.C.; Medeiros, Z.; Vii, I. Situação da filariose bancroftiana na Região Metropolitana do Recife: Estudo em uma área endêmica no Município de Jaboatão dos Guararapes, Pernambuco, Brasil [The occurrence and distribution of lymphatic filariasis in Greater Metropolitan Recife: The case of an endemic area in Jaboatão dos Guararapes, Pernambuco, Brazil]. Cad. Saúde Pública 2003, 19, 1497-1505. [CrossRef]

29. Noroes, J.; Addiss, D.; Cedenho, A.; Figueredo-Silva, J.; Lima, G.; Dreyer, G. Pathogenesis of filarial hydrocele: Risk associated with intrascrotal nodulescaused by death of adult Wuchereria bancrofti. Trans. R. Soc. Trop. Med. Hyg. 2003, 97, 561-566. [CrossRef]

30. Wilson, S.F.; Guarner, J.; Valme, A.L.; Louis-Charles, J.; Jones, T.L.; Addiss, D.G. Histopathologic Improvement with Lymphedema Management, Léogâne, Haiti. Emerg. Infect. Dis. 2004, 10, 1938-1946. [CrossRef]

31. Fox, L.M.; Wilson, S.F.; Lammie, P.J.; De Rochars, M.V.B.; Addiss, D.G.; Louis-Charles, J. Clinical correlates of filarial infection in haitian children: An association with interdigital lesions. Am. J. Trop. Med. Hyg. 2005, 73, 759-765. [CrossRef] [PubMed]

32. Dreyer, G.; Addiss, D.; Gadelha, P.; Lapa, E.; Williamson, J.; Dreyer, A. Interdigital skin lesions of the lower limbs among patients with lymphoedema in an area endemic for bancroftian filariasis. Trop. Med. Int. Health 2006, 11, 1475-1481. [CrossRef] [PubMed]

33. McPherson, T.; Persaud, S.; Singh, S.; Fay, M.P.; Addiss, D.; Nutman, T.; Hay, R. Interdigital lesions and frequency of acute dermatolymphangioadenitis in lymphoedema in a filariasis-endemic area. Br. J. Dermatol. 2006, 154, 933-941. [CrossRef] [PubMed]

34. Medeiros, Z.; Alves, A.; Brito, J.A.; Borba, L.; Santos, Z.; Costa, J.P.; Santo, M.E.D.E.; Netto, M.J.E. The present situation regarding lymphatic filariasis in Cabo de Santo Agostinho, Pernambuco, Northeast Brazil. Rev. Inst. Med. Trop. 2006, 48, 263-267. [CrossRef]

35. Freitas, H.; Vieira, J.B.; Braun, R.; Medeiros, Z.; Rocha, E.M.M.; Aguiar-Santos, A.; Fraiha, H.; Rocha, A. Workshop para avaliação da situação epidemiológica da filariose linfática no Município de Belém, Pará, norte do Brasil [Workshop to evaluate the epidemiologic situation of lymphatic filariasis in the Municipality of Belém, Pará, Northern Brazil]. Rev. Soc. Bras. Med. Trop. 2008, 41, 212-216. [CrossRef] [PubMed]

36. Aguiar-Santos, A.M.; Leal-Cruz, M.; Netto, M.J.; Carrera, A.; Lima, G.; Rocha, A. Lymph scrotum: An unusual urological presentation of lymphatic filariasis. A case series study. Rev. Inst. Med. Trop. 2009, 51, 179-183. [CrossRef] [PubMed]

37. Norões, J.; Figueredo-Silva, J.; Dreyer, G. Intrascrotal nodules in adult men as a marker for filarial granuloma in a bancroftian filariasis-endemic area. Am. J. Trop. Med. Hyg. 2009, 81, 317-321. [CrossRef] [PubMed]

38. Norões, J.; Dreyer, G. A Mechanism for Chronic Filarial Hydrocele with Implications for Its Surgical Repair. PLoS Negl. Trop. Dis. 2010, 4, e695. [CrossRef]

39. Rocha, A.; Marcondes, M.; Nunes, J.R.V.; Miranda, T.; Veiga, J.; Araújo, P.; Tenório, W.; Aguiar-Santos, A. Programa de controle e eliminação da filariose linfática: Uma parceria da Secretaria de Saúde de Olinda-PE, Brasil, com o serviço de referência nacional em filarioses / Elimination and control of lymphatic filariasis program: A partnership between the Department of Health in Olinda, Pernambuco state, Brazil and the national center of lymphatic filariasis. Rev. Patol. Trop. 2010, 39, $233-249$.

40. Netto, M.J.; Bonfim, C.; Brandão, E.; Santos, A.M.A.; Medeiros, Z. Burden of lymphatic filariasis morbidity in an area of low endemicity in Brazil. Acta Trop. 2016, 163, 54-60. [CrossRef]

41. Santana, J.R.; Souza, M.M.L.; Brandão, E.; Soares, H.P.R.; Melo, C.M.L.; Rocha, A.; da Silva, F.L. Perfil de pacientes com linfedema atendidos no serviço de referência nacional em filarioses da Fundação Oswaldo Cruz, Pernambuco, Brasil/Profile of lymphedema patients attended at the national center of lymphatic filariasis of the Oswaldo Cruz Foundation, Pernambuco, Brazil. Rev. Patol. Trop. 2016, 45, 387-397. 
42. Soares, H.P.D.S.; Rocha, A.; Aguiar-Santos, A.M.; Silva, B.S.; De Melo, C.M.L.; Andrade, M.D.A. Terapia complexa descongestiva com uso de material alternativo na redução e controle do linfedema em pacientes de área endêmica de filariose: Um ensaio clínico. Fisioter. Pesqui. 2016, 23, 268-277. [CrossRef]

43. Hettrick, H. Establishing a lymphatic filariasis morbidity plan for Haiti. Wound Pract. Res. 2017, 25, 146-148.

44. Jungmann, P.; Figueredo-Silva, J.; Dreyer, G. Bancroftian lymphangitis in northeastern Brazil: A histopathological study of 17 cases. J. Trop. Med. Hyg. 1992, 95, 114-118. [PubMed]

45. Figueredo-Silva, J.; Dreyer, G.; Guimarães, K.; Brandt, C.; Medeiros, Z. Bancroftian lymphadenopathy: Absence of eosinophils in tissues despite peripheral blood hypereosinophilia. J. Trop. Med. Hyg. 1994, 97, 55-59. [PubMed]

46. Norões, J.; Dreyer, G.; Santos, A.; Mendes, V.G.; Medeiros, Z.; Addiss, D. Assessment of the efficacy of diethylcarbamazine on adult Wuchereria bancrofti in vivo. Trans. R. Soc. Trop. Med. Hyg. 1997, 91, 78-81. [CrossRef]

47. Ch'en, T.T. Demonstration of microfilaricidal action of Hetrazan, antimony and arsenic preparations in man. Chin. Med. J. 1964, 83, 625-640.

48. Kar, S.K.; Mania, J.; Kar, P.K. Prevalence of lymphatic nodule in a bancroftian endemic population. Acta Trop. 1993, 55, 53-60. [CrossRef]

49. Devries, C.R. The role of the urologist in the treatment and elimination of lymphatic filariasis worldwide. BJU Int. 2002, 89, 37-43. [CrossRef]

50. Gyapong, J.O. The relationship between infection and disease in Wuchereria bancrofti infection in Ghana. Trans. R. Soc. Trop. Med. Hyg. 1998, 92, 390-392. [CrossRef]

51. Gyapong, J.O.; Webber, R.H.; Morris, J.; Bennett, S. Prevalence of hydrocele as a rapid diagnostic index for lymphatic filariasis. Trans. R. Soc. Trop. Med. Hyg. 1998, 92, 40-43. [CrossRef]

52. Pani, S.P.; Krishnamoorthy, K.; Rao, A.S.; Prathiba, J. Clinical manifestations in malayan filariasis infection with special reference to lymphoedema grading. Indian J. Med. Res. 1990, 91, 200-207. [PubMed]

53. Das, P.K.; Srividya, A.; Pani, S.P.; Ramaiah, K.D.; Vanamail, I.; Dhanda, V. Cumulative exposure and its relationshio with chronic filarial disease in bancroftian filariasis. Southeast Asian J. Trop. Med. Public Health 1994, 25, 516-521.

54. Dreyer, G.; Piessens, W. Lymphatic Filariasis; Nutman, T.B., Ed.; Imperial College Press: London, UK, 2000.

55. Gyapong, J.O.; Gyapong, M.; Evans, D.B.; Aikins, M.K.; Adjei, S. The economic burden of lymphatic filariasis in northern Ghana. Ann. Trop. Med. Parasitol. 1996, 90, 39-48. [CrossRef] [PubMed]

56. Gyapong, M.; Adjei, S. The Epidemiology of Acute Adenolymphangitis due to Lymphatic Filariasis in Northern Ghana. Am. J. Trop. Med. Hyg. 1996, 54, 591-595. [CrossRef] [PubMed]

57. Evans, D.B.; Gelband, H.; Vlassoff, C. Social and economic factors and the control of lymphatic filariasis: A review. Acta Trop. 1993, 53, 1-26. [CrossRef]

58. Hunter, J.M. Elephantiasis: A disease of development in North East Ghana. Soc. Sci. Med. 1992, 35, 627-645. [CrossRef]

59. Lammie, P.J.; Addiss, D.G.; Leonard, G.; Hightower, A.W.; Eberhard, M.L. Heterogeneity in Filarial-Specific Immune Responsiveness among Patients with Lymphatic Obstruction. J. Infect. Dis. 1993, 167, 1178-1183. [CrossRef]

60. Suma, T.K.; Shenoy, R.K.; Kumaraswami, V. A qualitative study of the perceptions, practices and socio-psychological suffering related to chronic brugian filariasis in Kerala, southern India. Ann. Trop. Med. Parasitol. 2003, 97, 839-845. [CrossRef] [PubMed]

61. Ahorlu, C.; Dunyo, S.K.; Koram, K.A.; Nkrumah, F.K.; Aagaard-Hansen, J.; Simonsen, P.E. Lymphatic filariasis related perceptions and practices on the coast of Ghana: Implications for prevention and control. Acta Trop. 1999, 73, 251-261. [CrossRef]

62. Dunyo, S.K.; Ahorlu, C.K.; Simonsen, P.E. Scarification as a risk factor for rapid progression of filarial elephantiasis. Trans. R. Soc. Trop. Med. Hyg. 1997, 91, 446. [CrossRef]

63. Moffatt, C.; Franks, P.; Doherty, D.; Williams, A.; Badger, C.; Jeffs, E.; Bosanquet, N.; Mortimer, P. Lymphoedema: An underestimated health problem. QJM Int. J. Med. 2003, 96, 731-738. [CrossRef] [PubMed]

64. Dreyer, G.; Addiss, D.; Dreyer, P.; Noroes, J. Basic Lymphedema Management: Treatment and Prevention of Problems Associated with Lymphatic Filariasis; Hollis Publishing Company: Hollis, NH, USA, 2002.

65. Debrah, L.B.; Mohammed, A.; Osei-Mensah, J.; Mubarik, Y.; Agbenyega, O.; Ayisi-Boateng, N.K.; Pfarr, K.; Kuehlwein, J.M.; Klarmann-Schulz, U.; Hoerauf, A.; et al. Morbidity management and surveillance of lymphatic filariasis disease and acute dermatolymphangioadenitis attacks using a mobile phone-based tool by community health volunteers in Ghana. PLoS Negl. Trop. Dis. 2020, 14, e0008839. [CrossRef] [PubMed]

66. Shenoy, R.K.; Suma, T.K.; Rajan, K.; Kumaraswami, V. Prevention of acute adeno-lymphangitis in bmgian filariasis: Comparison of the efficacy of ivermectin and diethylcarbamazine, each combined with local treatment of the affected limb. Ann. Troaical Med. Parasitol. 1998, 92, 587-594. [CrossRef] 